\title{
ANALISA DAN PERANCANGAN OTOMATISASI SURAT PENGANTAR RT BERBASIS SMS GATEWAY SEBAGAI PENERAPAN KONSEP PAPERLESS OFFICE
}

\author{
Yudie Irawan \\ Fakultas Teknik, Program Studi Sistem Informasi \\ Universitas Muria Kudus \\ Email: yudie.irawan@umk.ac.id
}

\begin{abstract}
ABSTRAK
Paperless merupakan salah satu upaya dalam mengurangi dampak negatif kerusakan lingkungan, yang berimplikasi pada kelestarian hutan. Teknologi informasi dan komunikasi telah banyak membantu mewujudkan konsep paperless pada instansi pendidikan, industri swasta maupun pemerintahan. Pada instansi pemerintahan belum banyak diterapkan konsep paperless ini karena terbentur aturan dan birokrasi yang mengharuskan pembuatan dokumen dengan menggunakan kertas. Salah satu rutinitas surat menyurat yang dilakukan oleh instansi pemerintahan adalah pada tingkat Rukun Tetangga (RT). Pada saat warga ingin membuat surat kependudukan maka harus melalui tingkat RT untuk mendapatkan surat pengantar sebagi syarat ke tingkat kelurahan. Pembuatan surat pengantar oleh RT sebenarnya dapat digantikan dengan fungsi aplikasi SMS Gateway karena nomor telepon genggam saat ini telah memiliki fungsi sebagai identitas diri. Teknologi SMS Gateway memungkinkan staf RT mengirimkan pesan singkat ke server kelurahan yang akan diterima sebagai data pemicu pembuatan surat kependudukan. Data yang ada dapat di integrasikan dengan data pemohon sehingga format SMS tidak terlalu panjang. Melalui metode ini maka pemohon tidak membutuhkan waktu yang lama untuk menunggu surat - surat kependudukan yang dibutuhkan karena saat staf RT mengirimkan SMS maka staf di kelurahan dapat memproses surat tersebut saat itu juga. Metode penelitian pada pengembangan sistem ini berdasarkan metode pengembangan sistem Waterfall model, sedangkan dalam level desain menggunakan metode perancangan sistem Unified Modelling Language. Hasil penelitian berupa pemodelan sistem yang disajikan dalam Business Use Case Diagram, Use Case Diagram dan Class Diagram, sedangkan perancangan basisdata ditampilkan dalam ER diagram.
\end{abstract}

Kata kunci: analisa, perancangan, otomatisasi, surat pengantar, rukun tetangga, paperless

\begin{abstract}
Paperless is an effort to reduce the negative impact of environmental degradation, which has implications for conservation of the forest. Information and communication technologies have been helped to implement the concept of the paperless such as in educational institutions, private industry or government. In government agencies, the concept of paperless have not been widely implemented due to the hard rules and bureaucracy that requires to using paper for many document. One routine correspondence that has became a frequently duty by government agencies is at the level of the Rukun Tetangga (RT). When people want to make a settlement letter then they have to go through the RT level to obtain a cover letter as a regulations to the village level. Making the cover letter by RT actually can be replaced with SMS Gateway application functions as a cell phone number now has been a wide function as an identity label. SMS Gateway technology may the staff of RT sending short messages to the server that will be accepted as a trigger of a letter. Existing data can be integrated with the applicant data so that the field of the applicant is not too long in the SMS format. Through this method, the applicant does not require a long time to wait for the letter. Since the staff RT sending the message, the village staff can immediately process the letter. The process of analysis and design, this development system is using development method Waterfall models, while the level design using Unified Modeling Language system design. The results of this research activity is a system models that show in Business Use Case Diagram, Use Case Diagrams and Class Diagrams and ER Diagram.
\end{abstract}

Keywords: analysis, design, automation, cover letter, rukun tetangga(RT), paperless.

\section{PENDAHULUAN}

Kerusakan lingkungan sangat berdampak pada manusia, hal ini akan meningkat resiko bencana alam. Oleh karena itu kita harus selalu memelihara ekosistem yang ada antara lain menjaga hutan, tanah, air serta udara untuk 
mempertahankan kelangsungan sumber daya alam yang mendukung kehidupan manusia. Salah satu usaha untuk menjaga hutan adalah dengan mulai memperkenalkan filosofi paperless. Konsep Paperless adalah mengurangi pemakaian kertas bukan meniadakan pemakaian kertas sama sekali. Karena idealnya hampir tidak mungkin untuk kantor tidak memakai kertas. Konsep Paperless ini dapat dilakukan dengan mengubah dokumen atau penggunaan kertas lainnya kebentuk digital [1]. Kita harus mulai mengurangi penggunaan kertas karena bahan utama kertas adalah kayu, dan untuk memproduksi 1 rim kertas diperlukan 1 batang pohon usia 5 tahun. Proses produksi kertas juga akan menghasilkan limbah yang berbentuk cair, gas dan padat yang harus dikelola dengan baik untuk mengurangi dampaknya pada kerusakan lingkungan.

Institusi pendidikan merupakan sektor terbanyak dalam menggunakan metode paperless. Hal ini dapat dilihat dari berkembangnya situs-situs yang menyediakan $e$-book sebagai referensi dalam sumber belajar [2]. Pada bidang akademik, paperless juga sudah digunakan pada pengerjaan tugas dan ujian. Dalam bidang pemerintahan konsep paperless diwujudkan dalam e-perkantoran(e-office) yaitu sebuah layanan untuk mendukung kegiatan perkantoran khususnya administrasi. E-office di Indonesia saat ini lebih banyak digunakan oleh kalangan swasta. Untuk di kalangan pemerintahan, e-office belum terlalu dikenal dan dikembangkan pemanfaatannya [3].

Keberadaan Rukun Tetangga (RT) dibutuhkan masyarakat untuk urusan pembuatan Kartu Tanda Penduduk (KTP), Kartu Keluarga (KK), surat pidah/domisili, ijin nikah dan ijin keramaian, kematian, dan perkara teknisadministratif lainnya. [4]. Tugas pembuatan surat - surat tersebut semuanya menggunakan kertas sebagai dokumen. Penulis melihat adanya peluang dalam pemanfaatan teknologi untuk mengurangi penggunaan kertas, sekaligus membantu meningkatkan pelayanan masyarakat di tingkat RT.

Perkembangan teknologi informasi dan komunikasi telah menjadi pilihan dalam mengurangi penggunaan kertas. Salah satu teknologi yang murah dan mudah digunakan adalah aplikasi sms gateway. Pada beberapa artikel sebelumnya, sms gateway digunakan sebagai alat penyebaran informasi, pemesanan produk atau layanan, permintaan layanan informasi, pendataan administrasi dan sistem monitoring.

Berdasarkan permasalahan diatas perlu dikembangkan pemanfaatan sms gateway menjadi pengganti surat pengantar sebagai upaya mengurangi penggunaan kertas dan meningkatkan kualitas pelayanan surat menyurat di tingkat RT. SMS gateway adalah solusi penerapan sistem yang murah dan mudah untuk dikembangkan di tingkat RT.

\section{METODOLOGI PENELITIAN}

\subsection{Sumber Data Primer}

Sumber data primer adalah data yang diperoleh langsung dari objek penelitian, baik melalui pengamatan maupun pencatatan terhadap obyek penelitian, meliputi :

a. Observasi

Observasi adalah pengumpulan data melalui pengamatan dan pencatatan terhadap gejala/peristiwa yang diselidiki pada objek penelitian secara langsung. Observasi dilakukan kepada warga dan staf RT dilingkungan penulis.

b. Wawancara

Wawancara adalah Pengumpulan data melalui tatap muka dan tanya jawab langsung dengan sumber data atau pihak-pihak yang berkepentingan pada bagian sekretariat. Wawancara dilakukan secara langsung kepada beberapa responden yang mewakili warga, staf RT dan petugas Kelurahan.

\subsection{Sumber Data Sekunder}

Sumber data sekunder adalah data yang diambil secara tidak langsung dari objek penelitian. Data ini diperoleh dari buku-buku, dokumentasi, dan literatur-literatur. Meliputi :

a. Studi Kepustakaan

Studi Kepustakaan adalah pengumpulan data dari buku-buku yang sesuai dengan tema SMS Gateway dan Paperless.

b. Studi Dokumentasi

Studi Dokumentasi adalah pengumpulan data dari literatur-literatur dan dokumentasi dari Internet, diktat, dan/atau sumber informasi lain..

\subsection{Metode Pengembangan Sistem}

Metode pengembangan sistem yang digunakan dalam perancangan sistem ini adalah Watterfall Model. Metode ini mudah dipahami dan digunakan karena memiliki konsep linear-sequential life cycle 
model. Metode ini direkomendasikan untuk projek yang sederhana dan memiliki permintaan yang sangat jelas[5], seperti pada projek penelitian ini. Waterfall model [6] terdiri dari beberapa tahap meliputi :

a. Perencanaan Sistem

Perencanaan ini meliputi pendefinisian tujuan-tujuan pembuatan program dan fasilitasfasilitas yang akan dilibatkan dalam pembuatan program. Dalam tahap ini peneliti berkosultasi dengan stakeholder [7], berkaitan dengan layak atau tidaknya program yang akan dibuat. Stakeholder adalah pihak - pihak yang memiliki kepentingan pada sistem yang telah ada maupun sistem yang baru. Stakeholder terdiri dari tenaga teknis dan tenaga non-teknis.

b. Analisis Kebutuhan Perangkat Lunak

Proses menganalisis dan pengumpulan kebutuhan sistem yang sesuai dengan domain informasi tingkah laku, unjuk kerja, dan antar muka (interface) yang diperlukan.

Proses ini dilakukan setelah memahami permasalahan dan memutuskan teknologi yang dipilih sebagai solusi dari permasalahan yang dingin dipecahkan. Pada tahapan ini dilakukan analisa perangkat keras dan perangkat lunak yang dibutuhkan untuk pengembangan sistem.

c. Desain

Proses desain akan menerjemahkan syarat kebutuhan ke sebuah perancangan perangkat lunak yang dapat diperkirakan sebelum dibuat coding. Proses ini berfokus pada: struktur data, arsitektur perangkat lunak, representasi interface, dan detail (algoritma) prosedural. Implementasi Sistem Merupakan prosedur yang digunakan untuk menyelesaikan desain sistem yang sudah dirancang. Setelah kebutuhan pengembangan sistem terpenuhi maka langkah yang dilakuka peneliti adalah membuat blue print sistem. Pada penelitian ini desain sistem disajikan dengan Unified Modelling Language. [8], [9], sedangkan desain database menggunakan model Entity Relationship [10], [11].

d. Pengkodeaan (Coding)

Pengkodean merupakan prses menerjemahkan desain ke dalam suatu bahasa yang bisa dimengerti oleh komputer. Pengkodean dilakukan sesuai dengan desain yang telah ada, walaupun pada pelaksanaannya terdapat peluang untuk menambah maupun mengurangi rancangan sistem untuk mendapatkan hasil akhir yang lebih baik. Selain perancangan aplikasi, perancangan database juga diimplementasikan dari bentuk akhir desain fisik ke tabel fisik. Aplikasi smsgateway yang akan digunakan adalah Gammu.

e. Pengujian

Proses pengujian dilakukan pada logika internal untuk memastikan semua pernyataan sudah diuji. Pengujian eksternal fungsional untuk menemukan kesalahan-kesalahan dan memastikan bahwa input akan memberikan hasil yang aktual sesuai yang dibutuhkan. Baik metode white box maupun black box, tujuannya adalah untuk menemukan jumlah maksimum kesalahan dengan jumlah usaha dan waktu yang minimum. [5].

f. Pemeliharaan

Perangkat lunak yang sudah disampaikan kepada pelanggan pasti akan mengalami perubahan. Perubahan tersebut bisa karena mengalami kesalahan karena perangkat lunak harus menyesuaikan dengan lingkungan (peripheral atau sistem operasi baru) baru, atau karena pelanggan membutuhkan perkembangan fungsional atau unjuk kerja .

\section{HASIL PENELITIAN DAN PEMBAHASAN}

Proses perancangan otomatisasi surat pengantar RT/RW berbasis sms gateway sebagai penerapan konsep paperless office, menghasilkan modul sesuai dengan fungsi yang dibutuhkan antara lain:

a. Pengolahan data user

Pada pengolahan data user terdapat fungsi untuk memberikan level kewenangan pada tiga level. Tiga kewenangan dalam sistem tersebut meliputi Administrator yang dilaksanakan oleh Petugas Kelurahan, Operator RT yang dilaksanakan oleh Petugas RT, dan Kepala Kelurahan sebagai pimpinan kelurahan yang menerima laporan. Level administrator adalah level tertinggi yang bertanggung jawab atas pengelolaan seluruh data yang ada. Level ini juga memiliki kemampuan mengatur setting sistem sesuai dengan kebutuhan. Level operator RT, adalah level yang dapat mengirim sms sesuai permintaan surat pengantar yang dibutuhkan warga dan melihat data historis surat pengantar yang pernah dibuat. Level untuk Kepala Kelurahan berfungsi untuk melihat laporan yang telah dibuat oleh petugas kelurahan. Kepala kelurahan dapat melakukan evaluasi terhadap laporan yang ada. 
b. Pengolahan Surat Pengantar

Modul ini digunakan untuk mengolah data SMS yang dikirimkan oleh petugas RT, yang berisi nomor surat dan keperluan surat pengantar. SMS ditentukan dalam format yang baku dan sesuai dengan field yang dibutuhkan dalam pembuatan surat seperti pada gambar 1 .

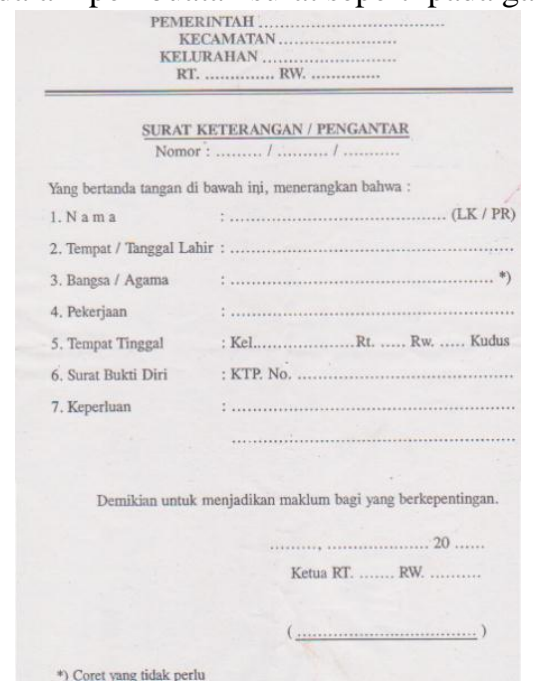

\section{Gambar 1. Contoh Formulir Surat Pengantar}

c. Pencetakan Surat Warga

Modul ini berfungsi untuk mencetak surat permohonan warga, seperti pengantar akte kematian, pengantar akte kelahiran, pengantar SKCK dan lain sebagainya berdasarkan surat pengantar yang dikirimkan melalui SMS dari petugas RT.

d. Laporan

Modul ini digunakan untuk menyajikan laporan surat pengantar dan surat keluar kelurahan yang dapat ditampillkan sesuai dasar permintaan periodik, jenis surat, nama pemohon dan laporan secara keseluruhan.

Analisa data dan informasi yang dibutuhkan sistem ini adalah :

a. Kebutuhan data :

1. Data warga

2. Data Kartu Keluarga

3. Data Petugas Kelurahan

4. Data Petugas RT

5. Data Surat Pengantar

6. Data Surat

7. Data Surat Keluar

b. Kebutuhan informasi :

1. Laporan Penggunaan Sistem

2. Laporan Pemohon

3. Laporan Surat Pengantar

4. Laporan Surat Keluar : (1) Kelahiran, (2) Kematian, (3) Pindah, (4) Pernikahan, (5) Kartu Keluarga(KK), (6) KTP, (7) Ijin keramaian

5. Laporan Petugas RT

Hasil analisa sistem disajikan dalam desain sistem yaitu Business Use Case Diagram dan Use Case Diagram. Pada Business Use Case Diagram terdapat tiga business worker dan dua business actor. Pada sistem ini memerlukan aktifitas login untuk mengenali kewenangan masing - masing user. Kewenangan user seperti telah diterangkan sebelumnya memiliki 3 level. Pada Business Use Case Diagram dijelaskan bahwa business actor Warga secara manual terlibat dalam pembuatan surat pengantar dan surat (kelurahan) seperti terlihat pada gambar 2. 


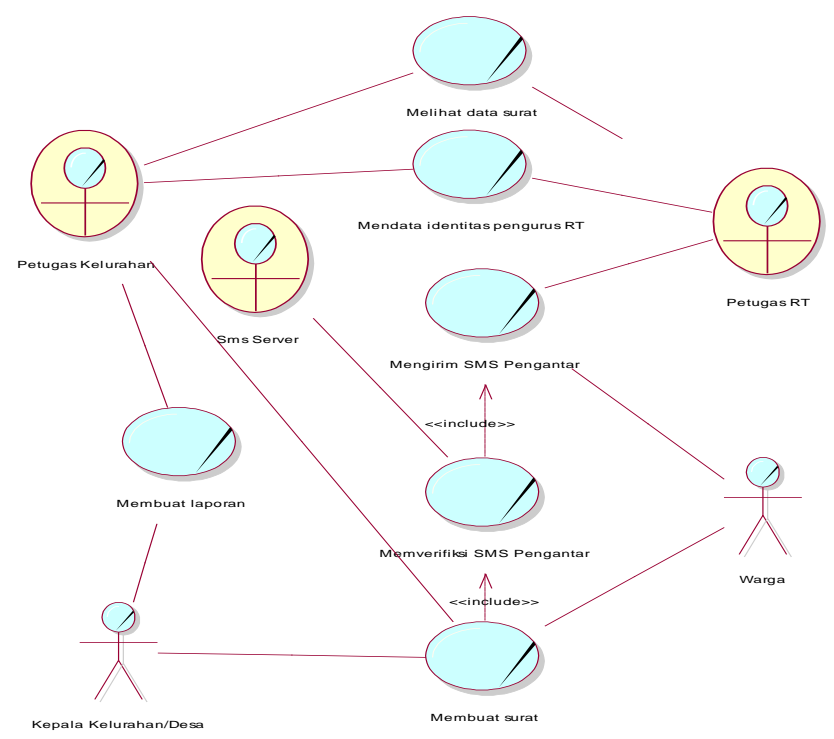

\section{Gambar 2. Business Use Case Diagram Sistem Otomatisasi Surat Pengantar RT}

Kegiatan otomatisasi tersistem dimulai saat Petugas RT mengirimkan SMS berformat ke server di kelurahan yang berisi NIK pemohon, keperluan dan tanggal surat. Dalam proses ini staf RT tidak perlu membuatkan surat pengantar yang harus dibawa warga ke kelurahan, sehingga mengurangi penggunaan kertas. Data wilayah RT dan RW pemohon diperoleh dari nomor telepon genggam Petugas RT, yang sekaligus sebagai media pengesahan dan validasi pengirim. Proses selanjutnya Petugas Kelurahan akan mendapatkan alert pengiriman SMS pada sistem dan membuka permintaan surat yang masuk sesuai dengan data yang dikirmkan melalui SMS. Verifikasi format SMS akan melalui aplikasi Gammu dan apabila ada kesalahan penulisan format akan direspon secara otomatis. Petugas kelurahan membuat surat yang diinginkan sesuai dengan data yang diterima dari SMS dan dimintakan pengesahan oleh Kepala Kelurahan. Proses ini memungkinkan warga langsung menerima surat yang diminta saat mereka datang ke Kelurahan tanpa menunggu lama. Hal ini lebih efisien karena memangkas birokrasi dan memangkas tahapan manual yang ada. Proses otomatisasi dapat dilihat pada gambar 3.

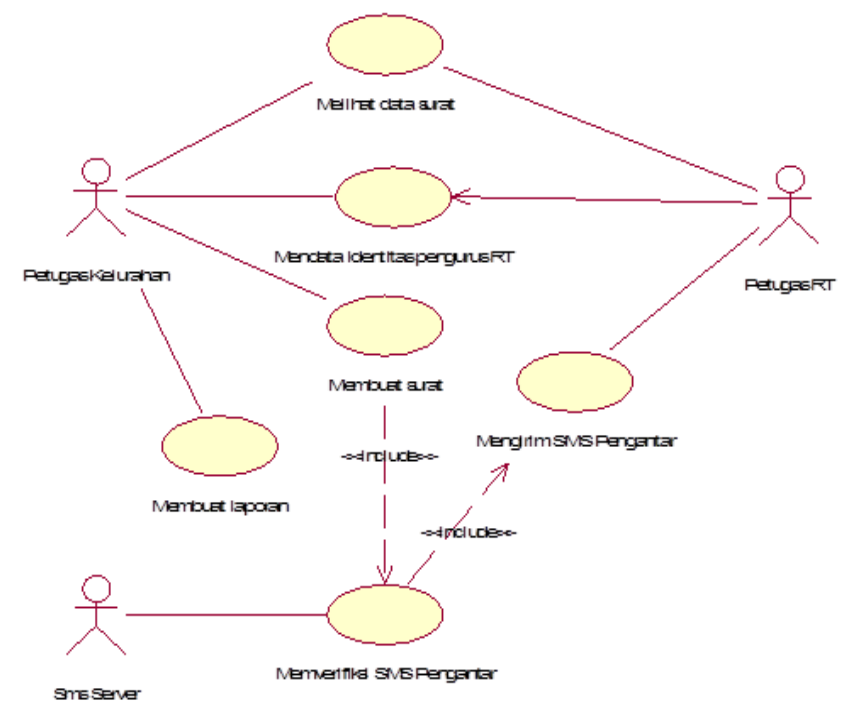

Gambar 3. Use Case Diagram Sistem Otomatisasi Surat Pengantar RT

Identifikasi objek yang digunakan dalam sistem ini dijabarkan dalam Class Diagram. Dari diagram ini dapat membantu menganalisa data - data yang perlu disimpan dalam storage yang diterjemahkan dalam bentuk table. Beberapa class mewakili objek penyimpanan data, seperti data surat pengantar, 
surat, petugas kelurahan, warga, KK, petugas RT dan kepala kelurahan. Hubungan antar class dapat dilihat pada gambar 4 .

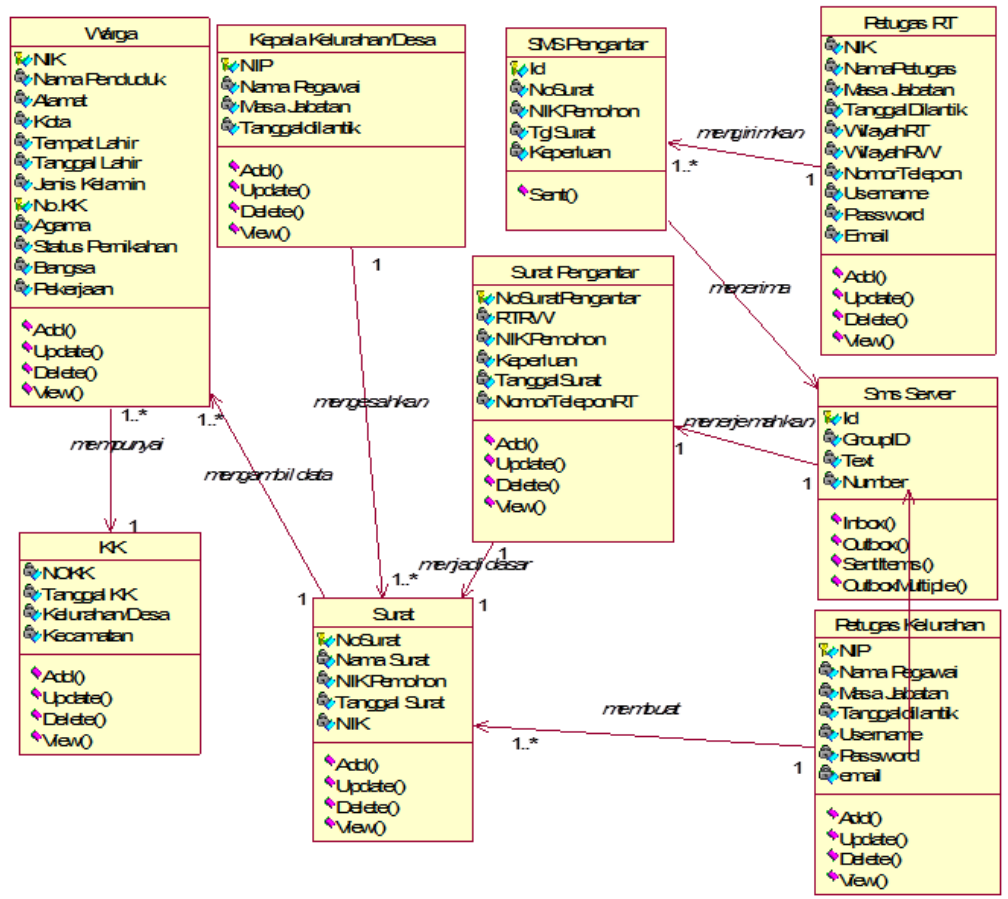

Gambar 4. Class Diagram Sistem Otomatisasi Surat Pengantar RT.

Pemodelan ER kadang-kadang dianggap sebagai pendekatan yang lengkap untuk merancang skema database tingkat logic. Hal ini tidak benar karena diagram ER hanya deskripsi perkiraan data, dibangun melalui evaluasi yang sangat subjektif dari informasi yang dikumpulkan selama analisis kebutuhan. Namun model ER nyaman untuk mewakili awal desain database, mengingat diagram ER mampu menggambarkan database, dan sudah ada pendekatan standar untuk menghasilkan skema database relasional.[11]. Perancangan basis data dalam penelitian ini dapat dilihat pada gambar 5.

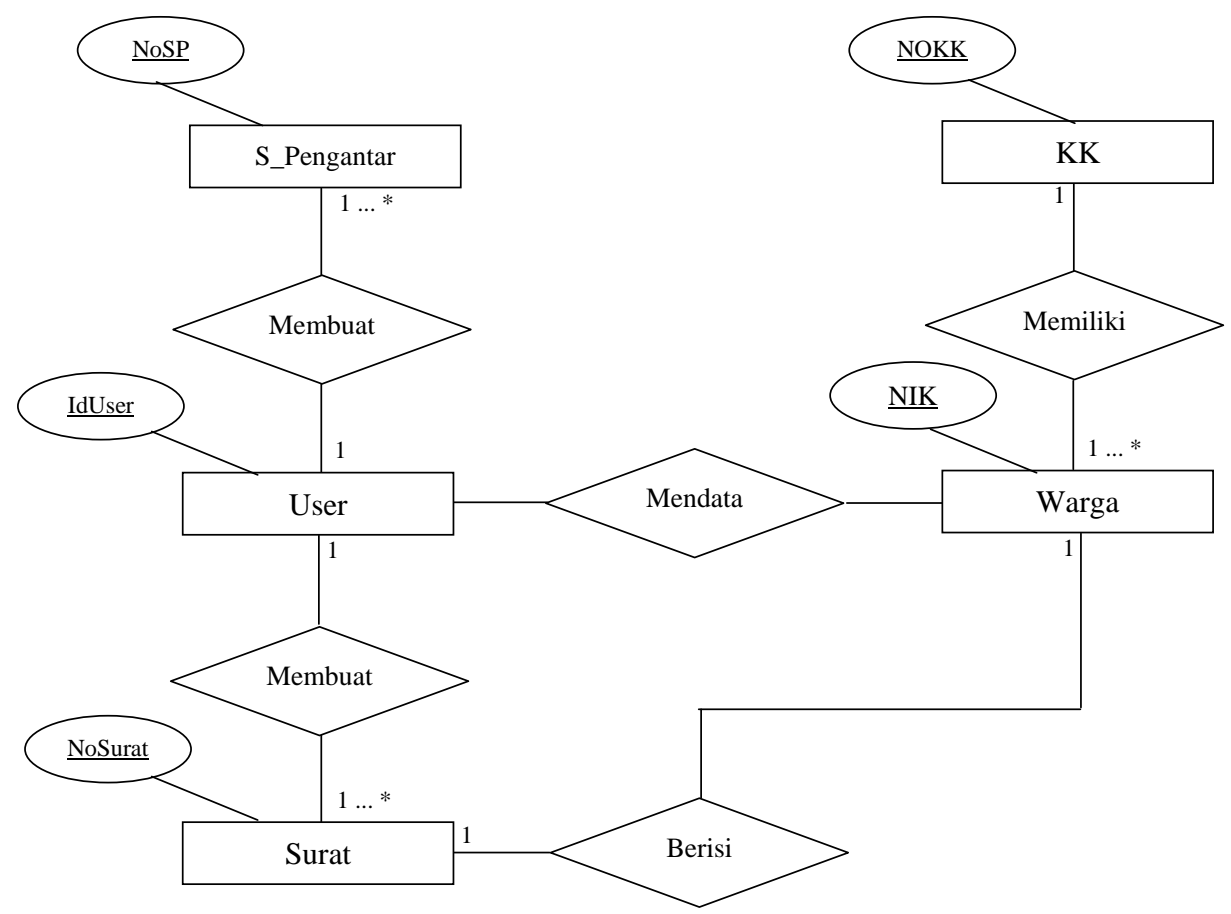

Gambar 5. ER Diagram Sistem Otomatisasi Surat Pengantar RT 


\section{KESIMPULAN DAN SARAN}

\subsection{Kesimpulan}

Hasil dari perancangan ini dapat disimpulkan antara lain :

a. Analisa dan perancangan Sistem Otomatisasi Surat Pengantar RT menggunakan metode pengembangan sistem Waterfall Model.

b. Perancangan Sistem Otomatisasi Surat Pengantar RT menggunakan metode perancangan sistem Unified Modelling Language, meliputi Business Use Case, Use Case Diagram dan Class Diagram. Sedangkan perancangan basis data menggunakan ER Diagram.

c. Hasil penelitian Sistem Otomatisasi Surat Pengantar RT berupa pemodelan sistem yang disajikan dalam Business Use Case, Use Case Diagram, Class Diagram dan ER Diagram.

\subsection{Saran}

Peneliti menyadari keterbatasan pengetahuan dan pengalaman yang dimiliki, walaupun demikian akan mencoba memberi saran yang mungkin akan dapat membangun. Adapun saran tersebut antara lain :

a. Hasil perancangan ini dapat dilanjutkan pada tahap implementasi dengan harapan akan mampu menyempurnakan desain database.

b. Implementasi yang akan dilakukan sebaiknya menggunakan sample yang ada di lapangan sehingga akan mendapatkan hasil yang lebih optimal.

c. Aplikasi SMS sebaiknya dapat dilengkapi dengan fitur digital signature untuk memastikan keamanan data yang diterima sesuai dengan data yang dikirim.

\section{DAFTAR PUSTAKA}

[1] Dewi, Kania Evita., Sufa'atin. Widianti, Utami Dewi. 2007. "Kajian Dokumentasi Surat Menuju Arah Paperless Unikom". Majalah Ilmiah UNIKOM.; Vol.12 No. 1: p. 61 - 68.

[2] Sim G, Tay AC, Priyanto I, Hickok J. 2014 . "Usage and Challenges of E-Books \& E-Readers in Southeast Asia:A Current Snapshot of the Issue. E-Books and E-Readers: Leveling the Playing Field or Widening the Digital Gap?

[3] Indrajit RE., 2005. E-goverment in Action. 1st ed. Yogyakarta: Andy Publisher.

[4] Launa., 2005. "Peluang Dan Tantangan Otonomi Daerah:(Studi Awal Tentang Pemberdayaan Peran Rukun Tetangga, Rukun Warga dan Dewan Kelurahan di Provinsi DKI Jakarta)”. INSANI. 2005 Februari; No.8.

[5] Stoica, Marian., Mircea, Marinela., Ghilic-Micu, Bogdan., 2013. "Software Development: Agile vs. Traditional". Informatica Economicăvol. 17, no. 4/2013

[6] Pressman RS, Maxim B., 2014. Software Engineering, a Practitioner's Approach. 8th ed. New York: McGraw-Hill.

[7] Whitten , Jeffrey L. B, Lonnie.D D, Kevin.C., 2001. Systems Analysis and Design Methods New York: McGraw publishers.

[8] Roques., 2004., UML in Practice : The Art of Modeling Software Systems demonstrated through Worked Examples and Solutions. New Jersey: Wiley publishers.

[9] A. Suhendar, H. Gunadi., 2002. Visual Modelling menggunakan UML dan Relational Rose Bandung: Informatika;.

[10] AlBahra LB. 2005, Analisis dan Desain Sistem Informasi . Yogyakarta: Graha Ilmu. 
Jurnal SIMETRIS, Vol 6 No 1 April 2015

ISSN: 2252-4983

[11] Ramakrisnan R, Gehrke J., 2003. Database Management System New York: McGraw Hil publisher 